\title{
Solar-forced shifts of the Southern Hemisphere Westerlies during the Holocene
}

\author{
V. Varma ${ }^{1}$, M. Prange ${ }^{1,2}$, F. Lamy ${ }^{2,3}$, U. Merkel ${ }^{2}$, and M. Schulz ${ }^{1,2}$ \\ ${ }^{1}$ Department of Geosciences, University of Bremen, 28334 Bremen, Germany \\ ${ }^{2}$ MARUM - Center for Marine Environmental Sciences, University of Bremen, Leobener Strasse, 28359 Bremen, Germany \\ ${ }^{3}$ Alfred Wegener Institute for Polar and Marine Research, 27568 Bremerhaven, Germany
}

Received: 18 March 2010 - Published in Clim. Past Discuss.: 31 March 2010

Revised: 9 March 2011 - Accepted: 10 March 2011 - Published: 4 April 2011

\begin{abstract}
The Southern Hemisphere Westerly Winds (SWW) constitute an important zonal circulation that influences large-scale precipitation patterns and ocean circulation. Variations in their intensity and latitudinal position have been suggested to exert a strong influence on the $\mathrm{CO}_{2}$ budget in the Southern Ocean, thus making them a potential factor affecting the global climate. In the present study, the possible influence of solar forcing on SWW variability during the Holocene is addressed. It is shown that a high-resolution iron record from the Chilean continental slope $\left(41^{\circ} \mathrm{S}\right)$, which is interpreted to reflect changes in the position of the SWW, is significantly correlated with reconstructed solar activity during the past 3000 years. In addition, solar sensitivity experiments with a comprehensive global climate model (CCSM3) were carried out to study the response of SWW to solar variability. Taken together, the proxy and model results suggest that centennial-scale periods of lower (higher) solar activity caused equatorward (southward) shifts of the annual mean SWW.
\end{abstract}

\section{Introduction}

The Southern Hemisphere Westerly Winds (SWW) constitute an important zonal circulation system that dominates the dynamics of Southern Hemisphere mid-latitude climate (e.g. Thresher, 2002; Shulmeister et al., 2004). Furthermore, they may influence the global ocean circulation through winddriven upwelling of deep water in the Southern Ocean (Toggweiler and Samuels, 1995; Kuhlbrodt et al., 2007; Sijp and England, 2009) and through the impact on the IndianAtlantic Ocean water exchange by Agulhas leakage (Sijp and

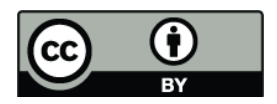

Correspondence to: V. Varma (vvarma@marum.de)
England, 2009; Biastoch et al., 2009). The significance of the SWW in the global climate system through their influence on the $\mathrm{CO}_{2}$ budget in the Southern Ocean has been discussed controversially (Toggweiler et al., 2006; Menviel et al., 2008; Tschumi et al., 2008; Anderson et al., 2009). Accordingly, understanding the variability and the impact of various forcings on the SWW remains a significant area of investigation.

Earlier studies have provided evidence for an equatorward displacement of the northern SWW margin during glacial periods (Lamy et al., 2004; Kaiser et al., 2005). Toggweiler et al. (2006) postulated feedback mechanisms involving the Southern Ocean $\mathrm{CO}_{2}$ air-sea gas exchanges, global temperature and position of SWW, whereby cooler climates would correspond to a more equatorward location of the SWW. Driving mechanisms and dynamics behind the variability in SWW are still unclear. During the Holocene, changes in seasonal insolation might have caused long-term variations in the structure, position and intensity of the SWW (Markgraf et al., 1992; Lamy et al., 2001; Jenny et al., 2003; Lamy et al., 2010).

Another significant forcing that influences climate on decadal to millennial time-scales is solar activity (e.g. Haigh, 1996; Cubasch et al., 1997; Bond et al., 2001; Versteegh, 2005; Spangehl et al., 2010), which could also be a potential driver for SWW variability. Van Geel et al. (2000) proposed solar activity as one of the possible factors for a shift in atmospheric circulation during the late Holocene around $2700 \mathrm{yr}$ BP. The abrupt decrease in solar activity during this period might have acted as a trigger for the glacier advancement towards the equator due to an equatorward shift of climatic zones along with the SWW (Van Geel et al., 2000). Solar-induced changes in stratospheric ozone through enhanced variability in the ultraviolet part of the solar spectrum were a postulated factor for shifting the SWW by influencing the tropospheric subtropical westerly jet through dynamical coupling between the atmospheric layers (Haigh, 1996).

Published by Copernicus Publications on behalf of the European Geosciences Union. 

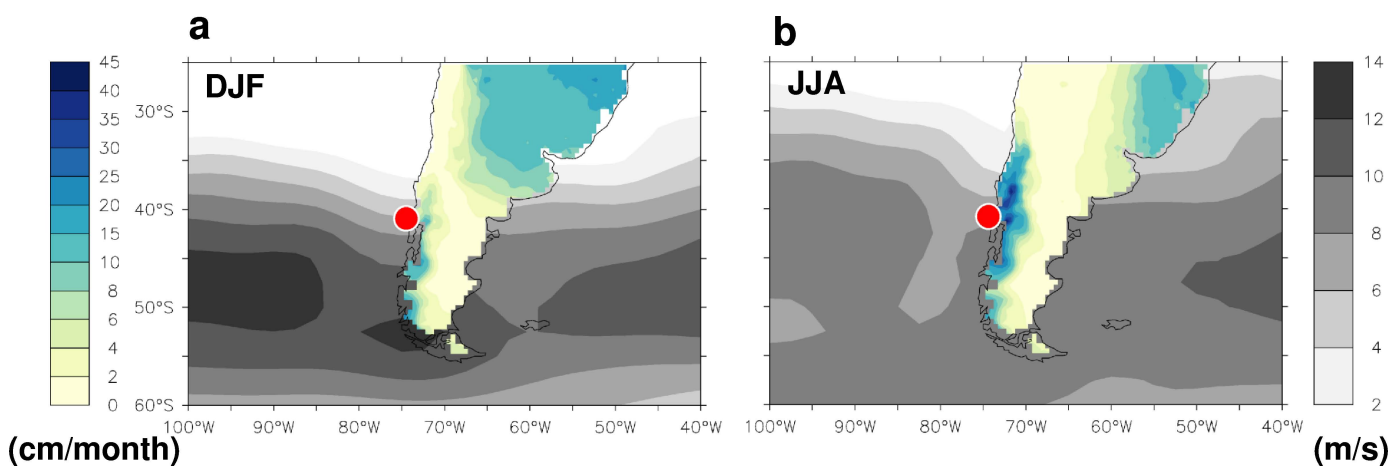

Fig. 1. Long-term climatological distribution of precipitation over land and $1000 \mathrm{hPa}$ zonal wind over oceans in the region of marine sediment core GeoB3313-1 located at $41^{\circ} \mathrm{S}, 74.45^{\circ} \mathrm{W}$ (red dot) for (a) austral summer (December/January/February) and (b) austral winter (June/July/August). During summer, the winds are more confined towards the south, resulting in decreased precipitation over the catchment represented by the core. During winter, surface winds (shown in grey shades) move towards the north, resulting in enhanced precipitation (shown in bluish shades) over the catchment represented by the core. Data: University of Delaware precipitation (http://climate.geog.udel. edu/ climate/), NCEP-NCAR reanalysis winds (Kalnay et al., 1996).

The potential role of solar forcing in Southern Hemisphere mid-latitude climate variability on the quasi-decadal timescale has been investigated by Thresher (2002), using observational data from the instrumental period. For longer timescales, the study of proxy data from natural archives is necessary. Here, we investigate the influence of centennialscale total solar irradiance (TSI) variations on the SWW using proxy data from the late Holocene in combination with sensitivity experiments, employing a state-of-the-art comprehensive global climate model. The results will lead us to the suggestion that equatorward (southward) shifts of the annual mean SWW occurred during centennial-scale periods of lower (higher) solar activity.

\section{Hints of solar-forced SWW shifts in a marine sediment core}

The mid-latitudes of Chile exhibit an extreme north-south precipitation gradient controlled by the latitudinal position of the SWW. Furthermore, local correlation analyses have shown that, in central and southern Chile, rainfall on the western side of the Andes is almost entirely determined by the westerlies (Garreaud, 2007). Therefore, any paleoclimate proxy that is primarily controlled by precipitation changes is a potential recorder of past changes of the SWW in this region. High-accumulation rate marine sediment core GeoB3313-1 from the Chilean continental slope $\left(41^{\circ} \mathrm{S}\right.$, $74.45^{\circ} \mathrm{W}$ ) provides a mid-to-late Holocene record of rainfall variability through its iron content (Lamy et al., 2001). Figure 1 shows the core location and illustrates the pattern of seasonal precipitation and zonal surface wind. During the austral summer, the northern margin of the SWW moves southwards and the core of the westerlies at around $50^{\circ} \mathrm{S}$ intensifies. The latitudinal movement of the wind belt's northern margin results in decreased precipitation over the catchment represented by the sediment core (Fig. 1a). Conversely, during the austral winter, the northern margin of the westerly wind belt is shifted towards the equator resulting in enhanced precipitation over the catchment represented by the sediment core (Fig. 1b). Given the strong influence of the SWW on the precipitation pattern, the iron data from core GeoB3313-1, which primarily reflect changes in paleoprecipitation, are likely to provide information on the SWW position. A higher content of iron in the sediment core region indicates drier conditions, probably due to southward shifted SWW, whereas a lower iron concentration might be indicative of wetter conditions suggesting northward shifted SWW (Lamy et al., 2001).

In order to find a possible correlation of the iron record with Holocene solar forcing, we use reconstructions of solar activity based on ${ }^{14} \mathrm{C}$ (Solanki et al., 2004) and ${ }^{10} \mathrm{Be}$ (Vonmoos et al., 2006). Comparison of the records suggests a possible link between the sun's radiative output and the SWW, indicating an equatorward (southward) shift of the annual mean SWW during periods of lower (higher) solar activity during the last 3000 years (Fig. 2). Linear correlations over this time interval, calculated using the Pearson coefficient are significant for both solar reconstructions. While the correlation coefficient $(r)$ for ${ }^{14} \mathrm{C}$ is relatively small (but statistically significant), the large correlation coefficient for ${ }^{10} \mathrm{Be}$ would suggest that ca. $20 \%$ (i.e., $r^{2}$ ) of late Holocene rainfall and hence SWW variability could be attributable to solar forcing.

\section{Model evidence for solar-forced SWW shifts}

To investigate the effect of TSI on the SWW, we carried out two sets of idealized experiments with constant and sinusoidal solar forcings using the comprehensive global climate model CCSM3 (Community Climate System Model version 3). NCAR's (National Center for Atmospheric 

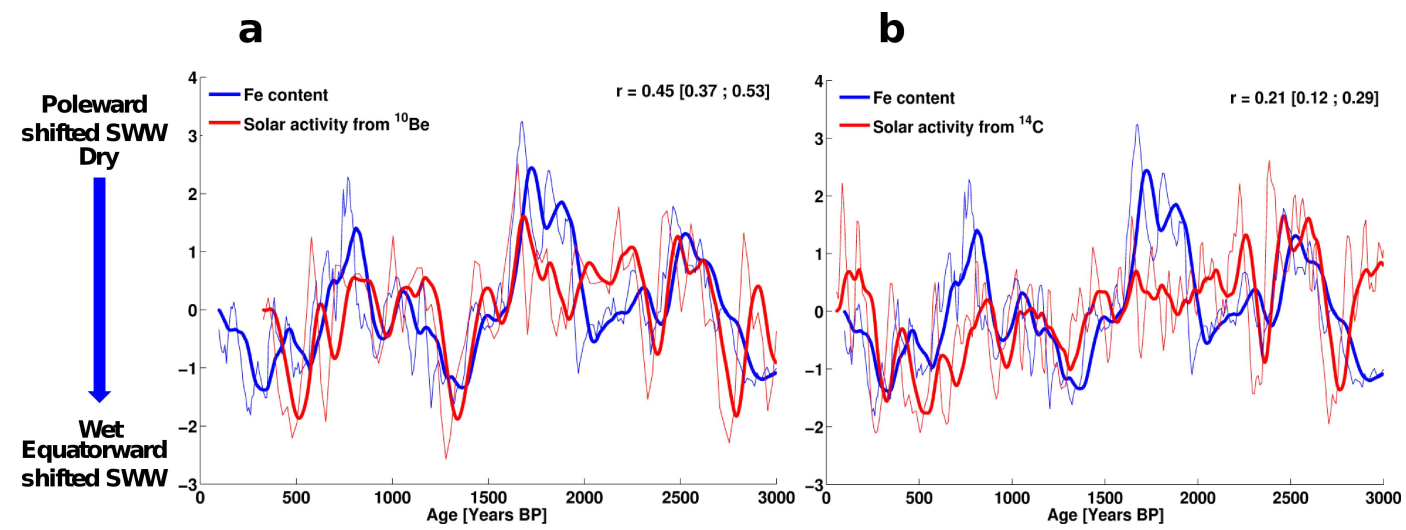

Fig. 2. Reconstructions of precipitation and hence, the position of the SWW (based on the GeoB3313-1 iron record) versus solar activity for the late Holocene. (a) Solar activity based on ${ }^{10} \mathrm{Be}$ (Vonmoos et al., 2006), (b) solar activity based on ${ }^{14} \mathrm{C}$ (Solanki et al., 2004). The time series have been linearly detrended and standardized. The bold curves show 100-year running means and the thin curves show the unsmoothed data. A lower content of iron stands for wetter conditions, suggesting northward shifted SWW (Lamy et al., 2001). Conversely, a higher content of iron reflects drier conditions essentially due to southward shifted SWW. Pearson correlation coefficients $(r)$ were calculated from the unsmoothed data. $95 \%$ confidence intervals (in brackets) were calculated using a bootstrap method, where autocorrelation has been taken into account (Mudelsee, 2003).

Research) CCSM3 is a state-of-the-art fully-coupled model, composed of four separate components representing atmosphere, ocean, land and sea-ice (Collins et al., 2006). Here, we employed the low-resolution version described in detail by Yeager et al. (2006). In this version, the resolution of the atmospheric component is given by $\mathrm{T} 31\left(3.75^{\circ}\right.$ transform grid), with 26 layers in the vertical, while the ocean has a nominal resolution of $3^{\circ}$ (like the sea-ice component) with a vertical resolution of 25 levels.

\subsection{Ensemble experiments with constant solar forcing}

Model runs were carried out with constant solar forcing, with the control run having a solar constant of $1365 \mathrm{~W} \mathrm{~m}^{-2}$ and the solar sensitivity experiments with a lower solar irradiance value of $1363 \mathrm{~W} \mathrm{~m}^{-2}$ (i.e. reduction by $0.15 \%$ ). Preindustrial boundary conditions were applied in all simulations following the protocol established by the Paleoclimate Modelling Intercomparison Project, Phase II (Braconnot et al., 2007). This forcing represents the average conditions of the late Holocene before the significant impact of humans, rather than a specific date, and it accounts for concentrations of greenhouse gases (e.g. $\mathrm{CO}_{2}$ concentration of $280 \mathrm{ppmv}$ ), ozone, sulphate and carbonaceous aerosols (Otto-Bliesner et al., 2006). After a 600-year spin-up, the control simulation (Merkel et al., 2010) was run for another 150 years while three sensitivity runs with a reduced solar constant were branched off at model years 600, 640 and 680, respectively. Each sensitivity run was integrated for 70 years, which is a typical timescale for the duration of solar "Grand minima" like the Wolf (1280-1350 AD), Spörer (1450-1550 AD) or Maunder (1645-1715 AD) Minimum. Our choice of TSI reduction of $2 \mathrm{~W} \mathrm{~m}^{-2}$ between solar maximum and solar minimum in the model experiments is consistent with recent observation and physics-based estimates (Steinhilber et al., 2009).

The three TSI sensitivity runs were branched off from very different SWW states (Fig. 3) and it could be noted from the time series of both intensity and position that the initial conditions for the different sensitivity runs were clearly different from each other and spanned the full range of $\pm 1 \sigma$. Indices of both the intensity and position of the annual mean SWW have been defined in terms of the average and difference between the latitudes $55^{\circ} \mathrm{S}$ (southern part of SWW belt) and $35^{\circ} \mathrm{S}$ (northern part of SWW belt) respectively. Spectral analyses performed for both SWW indices from the control run showed no decadal or multi-decadal cycles at the $95 \%$ significance level (not shown), thus ruling out a possible influence of low-frequency variability on the SWW response to reduced solar activity. Similar results hold for seasonal analyses (not shown). Moreover, we note that the three different TSI sensitivity experiments showed similar responses to reduced solar activity despite their different initial states. Taken together, we are therefore confident that the results from our three 70-year sensitivity experiments are robust with respect to the response of the SWW to TSI reduction.

The difference between sensitivity and control run (i.e. low minus high TSI simulation for a specific 70-year interval) was calculated for each ensemble member and, subsequently, the ensemble mean was taken and subjected to statistical analyses using a Student's t-test. Figure 4a shows the 70year-averaged annual mean zonal wind anomaly at $1000 \mathrm{hPa}$ in response to lower solar activity, for the ensemble mean. The model results suggest a shift of surface wind fields towards the equator in response to TSI reduction, consistent with the interpretation of the marine iron record discussed 
a

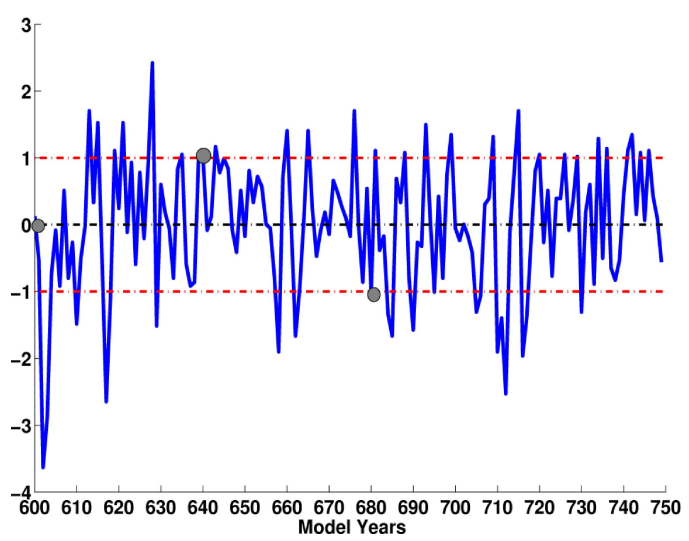

b

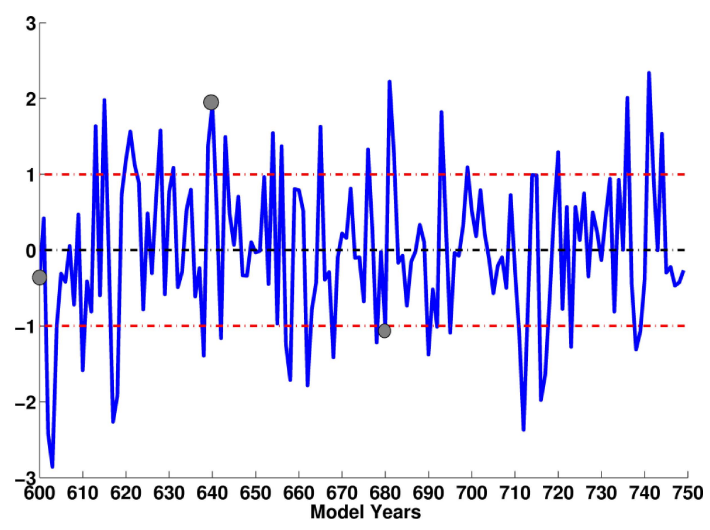

Fig. 3. Indices for annual-mean SWW intensity and position, respectively, in the model control run. (a) Zonally averaged zonal wind velocity at $1000 \mathrm{hPa}$ averaged between $55^{\circ} \mathrm{S}$ and $35^{\circ} \mathrm{S}$. (b) Difference in zonally averaged $1000 \mathrm{hPa}$ zonal winds between $55^{\circ} \mathrm{S}$ and $35^{\circ} \mathrm{S}$. Both indices have been standardized and \pm 1 denote one standard deviation (red dashed horizontal lines) while zero denotes the mean (black dashed horizontal lines). The years from which the three constant TSI sensitivity runs were branched off are marked as grey solid circles.
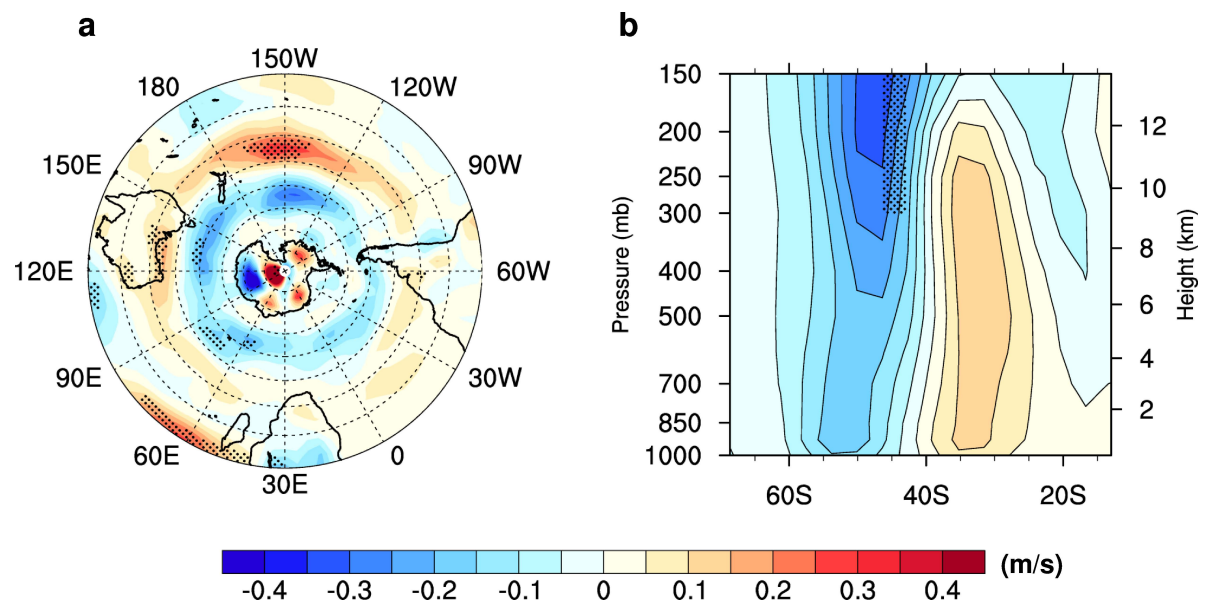

Fig. 4. Annual mean zonal wind anomaly (low minus high total solar irradiance) in the model ensemble mean, averaged over the entire 70year interval of the constant solar forcing experiment. (a) Zonal wind anomaly in the Southern Hemisphere at $1000 \mathrm{hPa}$, showing the clear equatorward shift of SWW. Latitudes marked start from $10^{\circ} \mathrm{S}$ and are placed at a $10^{\circ}$ interval. (b) Zonally averaged zonal wind anomaly for the Southern Hemisphere showing that the equatorward shift of SWW is pronounced even at upper levels of the troposphere. Stippling indicates significance of the anomaly at the 0.05 level (applying a Student's t-test).

above. Figure $4 \mathrm{~b}$ depicts the zonally averaged annual mean zonal wind anomaly as a function of latitude and height, showing that the equatorward SWW shift takes place at all levels in the troposphere. The wind anomaly patterns exhibit opposite signs for the different seasons, i.e. for lower solar activity, the SWW experience an equatorward shift during austral summer and a poleward shift during austral winter (Fig. 5). However, it is the austral summer pattern (December/January/February) which dominates the annual mean distribution, as can be seen by comparing Figs. 4 and 5 .

An equatorward shift of the SWW should result in increased precipitation over central Chile. Since a lowresolution version of CCSM3 has been used here, local features and in particular, orographic rainfall at the Andes cannot be fully captured. The model still simulates positive precipitation anomalies over the Chilean regions of enhanced westerlies, albeit with a very small magnitude and statistically not significant at the 0.05 significance level according to a t-test (not shown). We further note that a direct geographical comparison between model output and proxy data from a specific location could be affected by the fact that the summer SWW in CCSM3 are biased towards north (see http://www.ccsm.ucar.edu/experiments/ccsm3.0/atm/ b30.031-obs_801-820/set4/set4_DJF_U_NCEP_obsc.png for the present-day control run). The position of the maximum wind speed is simulated further equatorward, which is a 

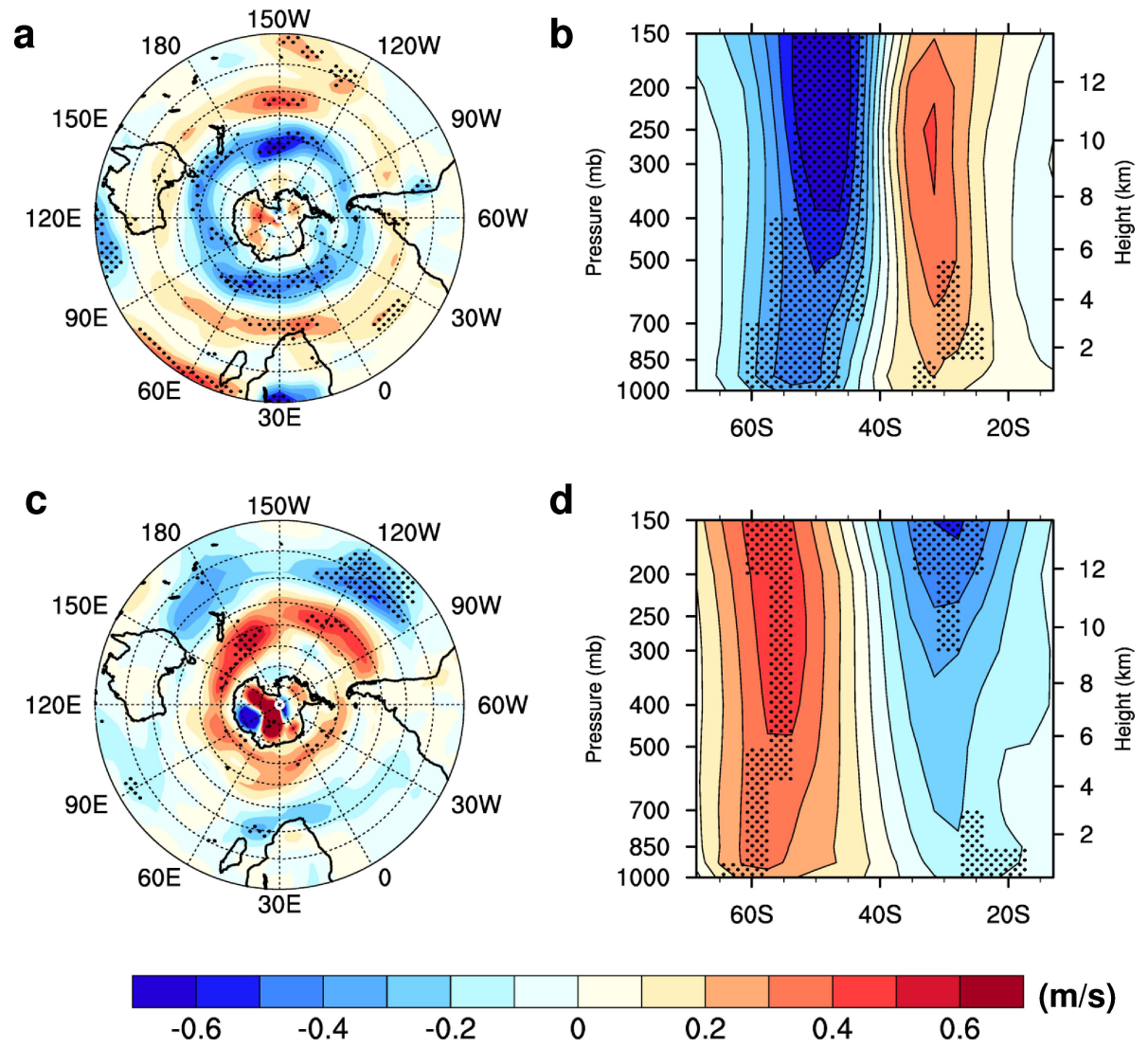

Fig. 5. Seasonal mean zonal wind anomaly (low minus high total solar irradiance) in the model ensemble mean, averaged over the entire 70 -year interval of the constant solar forcing experiment. (a) and (c) Zonal wind anomaly in the Southern Hemisphere at $1000 \mathrm{hPa}$ for austral summer (December/January/February) and austral winter (June/July/August), respectively. The wind anomaly patterns exhibit opposite signs for the different seasons, i.e. for lower solar activity, the SWW experience an equatorward shift during austral summer and a poleward shift during austral winter. Latitudes marked start from $10^{\circ} \mathrm{S}$ and are placed at $10^{\circ}$ interval. (b) and (d) Zonally averaged zonal wind anomaly for the Southern Hemisphere for austral summer (December/January/February) and austral winter (June/July/August), respectively. Stippling indicates significance of the anomaly at the 0.05 level (applying a Student's t-test).

common shortcoming in most coarse-resolution climate models (Rojas et al., 2009). This implies that the response of the SWW is likely simulated somewhat too far north.

\subsection{Experiments with sinusoidal solar forcing}

In order to test if the sensitivity of the model is sufficient to detect recurring solar-forced SWW shifts and if the response is dependent on the Holocene background climate, we carried out an additional set of experiments with idealized solar forcing. Each of these idealized experiments was initialized from an orbitally forced transient Holocene run ( 9 kyr BP to the present day) by taking the model years having orbital forcing corresponding to $8.5 \mathrm{kyr} \mathrm{BP}, 5.5 \mathrm{kyr} \mathrm{BP}$ and $2.5 \mathrm{kyr} \mathrm{BP}$, respectively (all other boundary conditions were set to the pre-industrial levels described above; an indepth analysis of the Holocene transient experiment will be the subject of a forthcoming study). From these initial conditions, the model was integrated for another 500 years to reach quasi-equilibrium for each of the three time slices. Subsequently, a sinusoidally varying solar irradiance forcing with a period of 200 years and an amplitude of $2 \mathrm{~W} \mathrm{~m}^{-2}$ was applied to the model for each time slice. The 200-year period was chosen to mimic the de Vries solar cycle, which is one of the most prominent solar cycles during the Holocene (e.g. Knudsen et al., 2009). With 700 years of model integration having sinusoidally varying solar irradiance, it was possible to include 3.5 de Vries solar cycles in each of the three experiments. Figure 6 shows the TSI forcing along with the position of the SWW (defined in terms of the difference between the latitudes $55^{\circ} \mathrm{S}$ and $35^{\circ} \mathrm{S}$ which represent the southern and northern parts of the SWW belt, respectively) for the early, mid and late Holocene experiments. In each experiment, forcing and response exhibit a strikingly similar temporal pattern, i.e. higher (lower) solar activity resulted in a poleward (equatorward) shift of the SWW. The three time series of the SWW position showed a statistical correlation with TSI significant at the $95 \%$ confidence level 


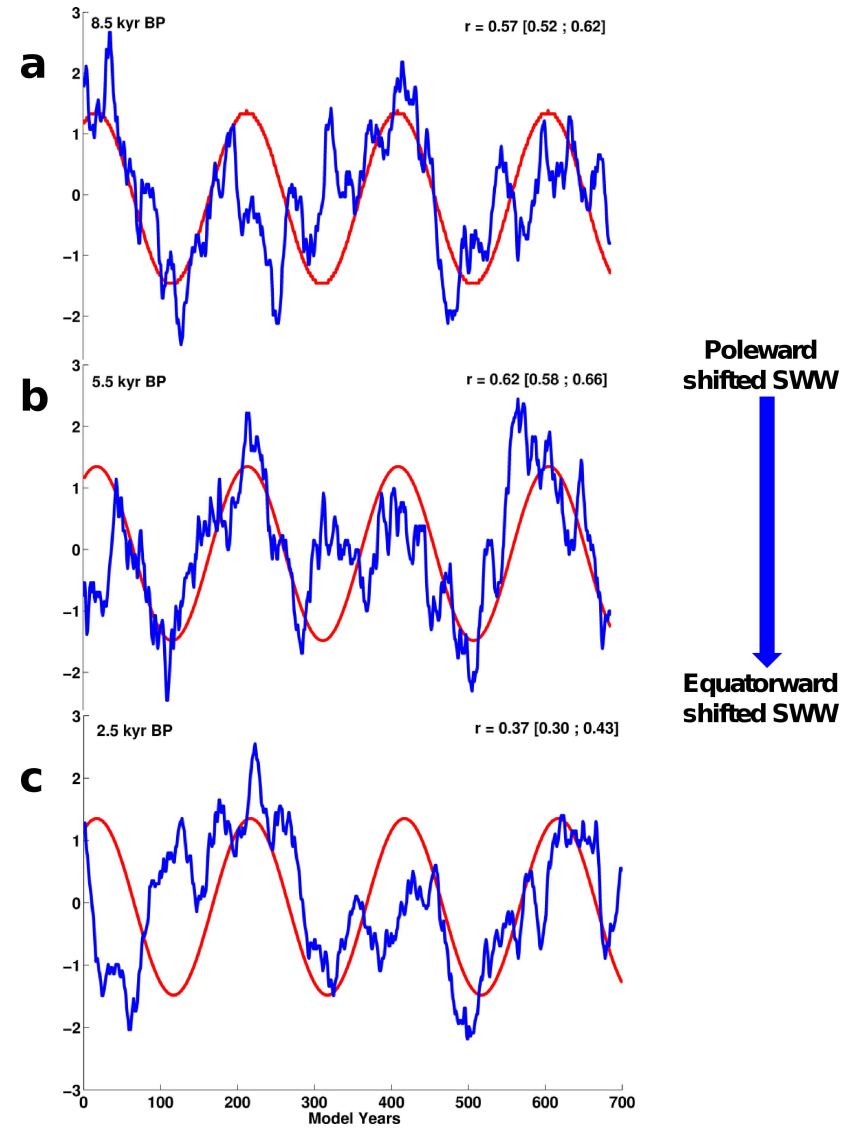

Fig. 6. Total solar irradiance (red curves) along with the position of annual mean SWW at $1000 \mathrm{hPa}$ (blue curves; defined in terms of the difference between the latitudes $55^{\circ} \mathrm{S}$ and $35^{\circ} \mathrm{S}$ which represent the southern and northern parts of the SWW belt) in the idealized sinusoidal solar-forcing experiments for early (a), mid (b) and late (c) Holocene. All time series have been standardized. The Pearson correlation coefficients $(r)$ were calculated after low-pass filtering using 70-year smoothing on zonal wind. 95\% bias corrected bootstrap confidence intervals (in brackets) were calculated using 10000 sub-samplings.

for centennial-scale variations. In addition, cross-spectral coherency was significant ( $95 \%$ level) at the period of 200 years using unsmoothed time series (not shown).

\section{Discussion}

Even though the influence and importance of the SWW on a global scale has been identified in previous studies, little is known about its variability and forcings. Correlation analysis between the GeoB3313-1 iron record and solar activity reconstructions suggests a significant influence of the sun's radiative output on the position of the SWW for the last 3000 years on a (multi-)centennial timescale. Though, for the early and mid-Holocene (i.e. prior to $3000 \mathrm{yr} \mathrm{BP}$ ), the correlation based on proxy records is close to zero (not shown), the model results from the sinusoidal solar forcing experiments do not suggest a weakening of the solar influence on the SWW in the early and mid-Holocene (Fig. 6). It is possible that this incongruity is due to dating uncertainties in the deeper section of core GeoB3313-1. We emphasize that all the proxy records used in this study are given on their own age scale, which may have adverse or positive effects on the correlation.

The climate model used in this study has a poorly resolved stratosphere and does not include feedbacks associated with the effect of enhanced variability in the ultraviolet part of the solar spectrum on photochemical dissociation rates and the subsequent impact on stratospheric ozone (Haigh, 1999; Rind et al., 2008). Instead, applied changes in TSI mostly affect the climate system through shortwave absorption by the surface, whereas less direct heating by solar radiation takes place at higher levels of the atmosphere. Note that almost $70 \%$ of shortwave radiation that enters the atmosphere and is not reflected back to space, is absorbed at the surface (Kiehl and Trenberth, 1997, and also in our model simulations). Therefore, the climate response in our experiment is mainly through "bottom-up mechanisms" (Meehl et al., 2009). By contrast, a "top-down" mechanism, which influences the troposphere via stratospheric ozone responses to variations in ultraviolet radiation, has been proposed by Haigh (1996). In her model, increase in ultraviolet radiation and resulting rise in ozone concentration, induced heating in the lower stratosphere during the Southern Hemisphere summer. As a consequence, strengthened stratosphere easterly winds caused the tropospheric subtropical westerly jets to move poleward, the tropical Hadley cell to broaden, and the SWW to move southward. "Bottom-up" and "top-down" mechanisms are not mutually exclusive. The model by Haigh (1996) used fixed sea surface temperatures and, hence, is unable to simulate "bottom-up" mechanisms that are important in our coupled climate model. We therefore suggest that the processes linking solar variability to the SWW in the two different models may complement each other, thus leading to a stronger total response than given by each individual process alone.

In order to get some insight into the "bottom-up" processes involved in our low-TSI experiment, simulated surface temperature anomalies are analyzed from the ensemble experiments with constant (70-year long) solar forcing (Fig. 7). As expected, a general surface cooling is induced by the TSI reduction (Fig. 7a). In addition to this general cooling, a more pronounced reduction in surface temperature is observed in the mid latitudes of, e.g., the central South Pacific sector (Fig. 7a, c, and d). By means of general atmospheric circulation modelling and scaling arguments, it has recently been shown that a reduction of the mean global surface temperature decreases the width of the Hadley cell (Frierson et al., 2007) and shifts the eddy-driven surface westerlies that result from the balance between vertically integrated eddy momentum convergence and surface drag towards the equator (Lu et al., 2010). Since the reduction in TSI is only $0.15 \%$, 

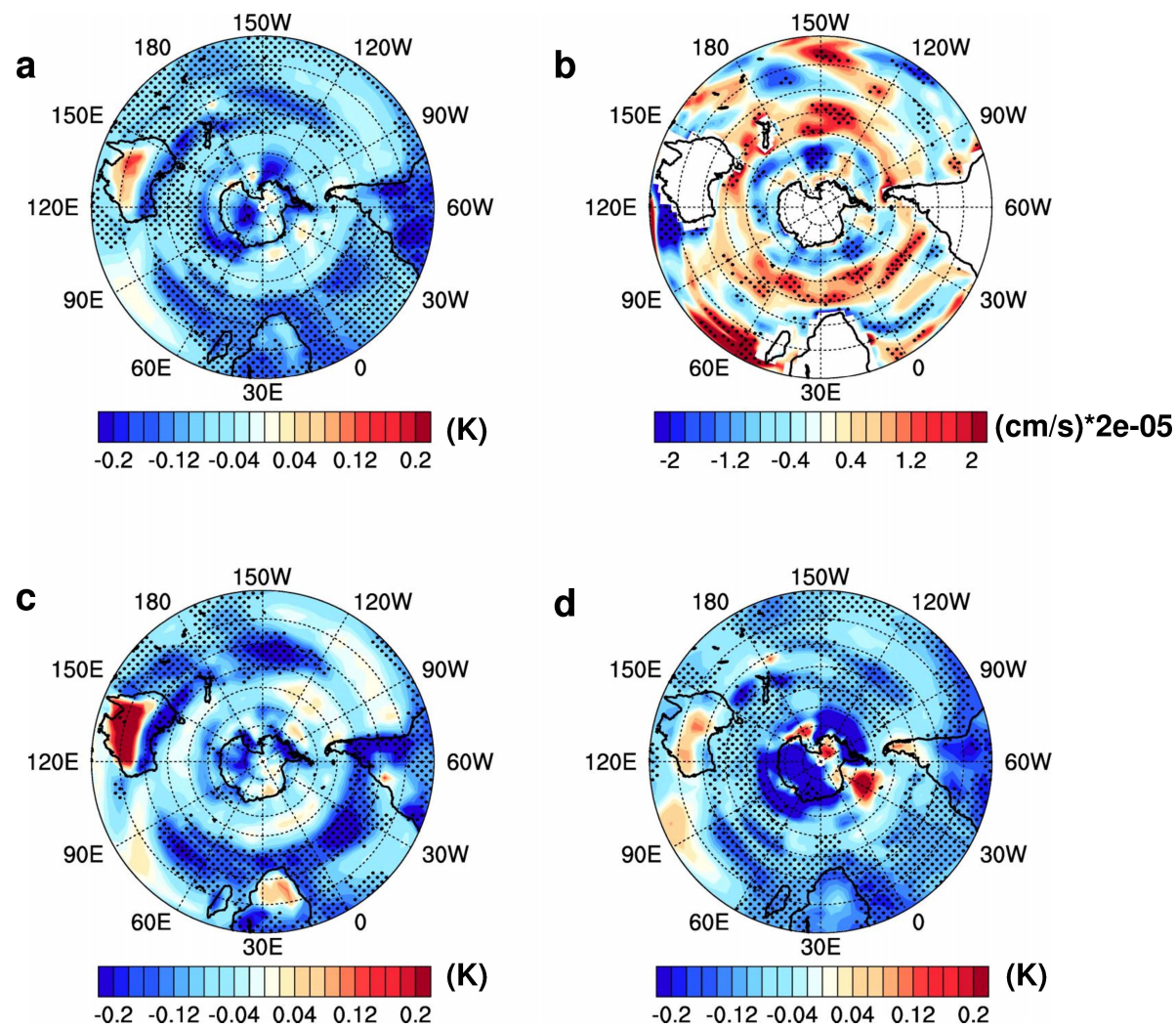

Fig. 7. Surface temperature anomalies (low minus high total solar irradiance) and the austral summer upwelling anomaly in the model ensemble mean, averaged over the entire 70-year interval of the constant solar forcing experiment. (a), (c) and (d) Surface temperature anomaly in the Southern Hemisphere for annual mean, austral summer (December/January/February) and austral winter (June/July/August), respectively. (b) Austral summer (December/January/February) upwelling (vertical velocity) anomaly at $30 \mathrm{~m}$ depth in the Southern Hemisphere. Stippling indicates significance of the anomaly at the 0.05 level (applying a Student's t-test). Latitudes marked start from $10^{\circ} \mathrm{S}$ and are placed at $10^{\circ}$ interval.

the global cooling effect is small and additional feedbacks are required to induce a significant change in the westerlies. One important feedback is associated with enhanced Ekman divergence and resulting upwelling (vertical velocity) around $\sim 40^{\circ} \mathrm{S}$ in austral summer (Fig. 7b). The upwelled cold water is transported northward in the Ekman surface layer, leading to enhanced SST cooling just north of $\sim 40^{\circ} \mathrm{S}$ (Fig. 7c). This cooling results in a meridional SST gradient anomaly that lies very close to (or just equatorward of) the subtropical jet. It has been shown that such an anomalous subtropical surface temperature gradient causes a strengthening of the jet along with an equatorward shift of the eddy-driven surface westerlies (Brayshaw et al., 2008; Lu et al., 2010), thus providing a positive feedback on the initial SWW shift in our simulations.

In austral winter, the coldest surface temperature anomalies are found around Antarctica (Fig. 7d), mainly due to increased sea-ice concentrations (up to 7\%) reducing oceanatmosphere heat fluxes and increasing the surface albedo. The resulting stronger meridional surface temperature gradient at high latitudes, however, is accompanied by a poleward shift of the surface westerlies (Chen et al., 2010; Lu et al., 2010), due to enhanced high-latitude baroclinic wave generation. This results in a winter SWW shift that is opposite to the other seasons.

\section{Conclusions}

Evidence for a significant solar influence on climate is rapidly growing based on natural archives from the Northern Hemisphere. Proxy data from the Southern Hemisphere, however, are notoriously sparse (Versteegh, 2005). Here, we presented proxy and model evidence that centennialscale variability in the position of the annual mean SWW has been influenced by fluctuations in solar activity at least during the past 3000 years. Periods of lower solar activity were associated with annual-mean equatorward shifts of the SWW, whereas periods of higher solar activity were linked to annual-mean poleward displacements of the SWW. Our idealized experiments with sinusoidal solar forcing show that the model response to solar forcing on the centennial time 
scale is a robust feature, independent of the Holocene background climate state. Based on our model evidence, as well as the proxy indication, we propose that the role of the sun in modifying Southern Hemisphere tropospheric circulation patterns has probably been underestimated in model simulations of past climate change. The potential role of solar forcing, along with feedbacks involving ocean and sea-ice dynamics, may further complicate the prediction of future SWW shifts.

Acknowledgements. This work was funded through the DFG (Deutsche Forschungsgemeinschaft, German Research Foundation) Priority Programme "INTERDYNAMIK" and through the DFG Research Center/Cluster of Excellence "The Ocean in the Earth System". We are indebted to Jürg Beer and Sami Solanki for providing the solar activity reconstructions as well as to Bruce Briegleb and Bette Otto-Bliesner for providing CCSM3 pre-industrial boundary conditions. We thank Axel Timmermann for stimulating discussions. We are also thankful to the two anonymous reviewers for their valuable comments and suggestions for improving the paper. We also thank PAGES for sponsoring the publication of this article. CCSM3 simulations were performed on the IBM supercomputer of the Norddeutscher Verbund für Hochund Höchstleistungsrechnen (HLRN). We also acknowledge the use of the NCAR Command Language (NCL) and NOAA/PMEL's Ferret in our data analysis and visualization herein. SimStat (Statistical Analysis and Simulation Software) was used to calculate the bootstrap confidence intervals.

Edited by: B. L. Otto-Bliesner

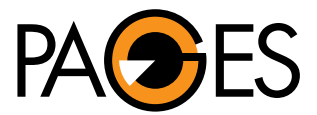

The publication of this article was sponsored by PAGES.

PAST GLOBAL CHANGES

\section{References}

Anderson, R. F., Ali, S., Bradtmiller, L. I., Nielsen, S. H. H., Fleisher, M. Q., Anderson, B. E., and Burckle, L. H.: WindDriven Upwelling in the Southern Ocean and the Deglacial Rise in Atmospheric $\mathrm{CO}_{2}$, Science, 323, 1443-1448, 2009.

Biastoch, A., Böning, C. W., Schwarzkopf, F. U., and Lutjeharms, J. R. E.: Increase in Agulhas leakage due to poleward shift of Southern Hemisphere westerlies, Nature, 462, 495-498, 2009.

Bond, G., Kromer, B., Beer, J., Muscheler, R., Evans, M. N., Showers, W., Hoffmann, S., Lotti-Bond, R., Hajdas, I., and Bonani, G.: Persistent Solar Influence on North Atlantic Climate During the Holocene, Science, 294, 2130-2136, 2001.

Braconnot, P., Otto-Bliesner, B., Harrison, S., Joussaume, S., Peterchmitt, J.-Y., Abe-Ouchi, A., Crucifix, M., Driesschaert, E., Fichefet, Th., Hewitt, C. D., Kageyama, M., Kitoh, A., Laîné, A., Loutre, M.-F., Marti, O., Merkel, U., Ramstein, G., Valdes, P., Weber, S. L., Yu, Y., and Zhao, Y.: Results of PMIP2 coupled simulations of the Mid-Holocene and Last Glacial Maximum Part 1: experiments and large-scale features, Clim. Past, 3, 261277, doi:10.5194/cp-3-261-2007, 2007.
Brayshaw, D. J., Hoskins, B., and Blackburn, M.: The Storm-Track Response to Idealized SST Perturbations in an Aquaplanet GCM, J. Atmos. Sci., 65, 2842-2860, doi:10.1175/2008JAS2657.1, 2008.

Chen, G., Plumb, R. A., and Lu, J.: Sensitivities of zonal mean atmospheric circulation to SST warming in an aqua-planet model, Geophys. Res. Lett., 37, L12701, doi:10.1029/2010GL043473, 2010.

Collins, W. D., Bitz, C. M., Blackmon, M. L., Bonan, G. B., Bretherton, C. S., Carton, J. A., Chang, P., Doney, S. C., Hack, J. J., Henderson, T. B., Kiehl, J. T., Large, W. G., McKenna, D. S., Santer, B. D., and Smith, R. D.: The Community Climate System Model Version 3 (CCSM3), J. Climate, 19, 2122-2143, 2006.

Cubasch, U., Voss, R., Hegerl, G. C., Waszkewitz, J., and Crowley, T. J.: Simulation of the influence of solar radiation variations on the global climate with an ocean-atmosphere general circulation model, Clim. Dynam., 13, 757-767, 1997.

Frierson, D. M. W., Lu, J., and Chen, G.: Width of the Hadley cell in simple and comprehensive general circulation models, Geophys. Res. Lett., 34, L18804, doi:10.1029/2007GL031115, 2007.

Garreaud, R. D.: Precipitation and Circulation Covariability in the Extratropics, J. Climate, 20, 4789-4797, 2007.

Haigh, J. D.: The impact of solar variability on Climate, Science, 272, 981-984, 1996.

Haigh, J. D.: Modelling the impact of solar variability on climate, J. Atmos. Sol.-Terr. Phy., 61, 63-72, 1999.

Jenny, B., Wilhelm, D., and Valero-Garcés, B. L.: The Southern Westerlies in Central Chile: Holocene precipitation estimates based on a water balance model for Laguna Aculeo ( $\left.33^{\circ} 50^{\prime} \mathrm{S}\right)$, Clim. Dynam., 20, 269-280, 2003.

Kaiser, J., Lamy, F., and Hebbeln, D.: A 70-kyr sea surface temperature record off southern Chile (Ocean Drilling Program Site 1233), Paleoceanography, 20, PA4009, doi:10.1029/2005PA001146, 2005.

Kalnay, E., Kanamitsu, M., Kistler, R., Collins, W., Deaven, D., Gandin, L., Iredell, M., Saha, S., White, G., Woollen, J., Zhu, Y., Leetmaa, A., Reynolds, R., Chelliah, M., Ebisuzaki, W., Higgins, W., Janowiak, J., Mo, K. C., Ropelewski, C., Wang, J., Jenne, R., and Joseph, D.: The NCEP/NCAR 40-Year Reanalysis Project, B. Am. Meteorol. Soc., 77, 437-471, 1996.

Kiehl, J. and Trenberth, K.: Earth's annual global mean energy budget, B. Am. Meteorol. Soc., 78, 197-206, 1997.

Knudsen, M. F., Riisager, P., Jacobsen, B. H., Muscheler, R., Snowball, I., and Seidenkrantz, M. S.: Taking the pulse of the Sun during the Holocene by joint analysis of ${ }^{14} \mathrm{C}$ and ${ }^{10} \mathrm{Be}$, Geophys. Res. Lett., 36, L16701, doi:10.1029/2009GL039439, 2009.

Kuhlbrodt, T., Griesel, A., Montoya, M., Levermann, A., Hofmann, M., and Rahmstorf, F.: On the driving processes of the Atlantic meridional overturning circulation, Rev. Geophys., 45, RG2001, doi:10.1029/2004RG000166, 2007.

Lamy, F., Hebbeln, D., Rohl, U., and Wefer, G.: Holocene rainfall variability in southern Chile: a marine record of latitudinal shifts of the Southern Westerlies, Earth Planet. Sc. Lett., 185, 369-382, 2001.

Lamy, F., Kaiser, J., Ninnemann, U., Hebbeln, D., Arz, H. W., and Stoner, J.: Antarctic Timing of Surface Water Changes off Chile and Patagonian Ice Sheet Response, Science, 304, 1959-1962, 2004. 
Lamy, F., Kilian, R., Arz, H. W., Francois, J. P., Kaiser, J., Prange, M., and Steinke, T.: Holocene changes in the position and intensity of the southern westerly wind belt, Nat. Geosci., 3, 695-699, 2010.

Lu, J., Chen, G., and Frierson, D. M. W.: The position of the midlatitude storm track and eddy-driven westerlies in aquaplanet AGCMs, J. Atmos. Sci., 67, 3984-4000, 2010.

Markgraf, V., Dodson, J. R., Kershaw, P. A., McGlone, M. S., and Nicholls, N.: Evolution of late Pleistocene and Holocene climates in the circum-South Pacific land areas, Clim. Dynam., 6, 193-211, 1992.

Meehl, G. A., Arblaster, J. M., Matthes, K., Sassi, F., and van Loon, H.: Amplifying the Pacific Climate System Response to a Small 11-Year Solar Cycle Forcing, Science, 325, 1114-1118, 2009.

Menviel, L., Timmermann, A., Mouchet, A., and Timm, O.: Meridional reorganizations of marine and terrestrial productivity during Heinrich events, Paleoceanography, 23, PA1203, doi:10.1029/2007PA001445, 2008.

Merkel, U., Prange, M., and Schulz, M.: ENSO variability and teleconnections during glacial climates, Quaternary Sci. Rev., 29, 86-100, 2010.

Mudelsee, M.: Estimating Pearson's correlation coefficient with bootstrap confidence interval from serially dependent time series, Math. Geol., 35, 651-665, 2003.

Otto-Bliesner, B. L., Tomas, R., Brady, E. C., Ammann, C., Kothavala, Z., and Clauzet, G.: Climate sensitivity of moderateand low-resolution versions of CCSM3 to preindustrial forcing, J. Climate, 19, 2567-2583, 2006.

Rind, D., Lean, J., Lerner, J., Lonergan, P., and Leboissitie, A.: Exploring the stratospheric/tropospheric response to solar forcing, J. Geophys. Res.-Atmos., 113, D24103, doi:10.1029/2008JD010114, 2008.

Rojas, M., Moreno, P., Kageyama, M., Crucifix, M., Hewitt, C., Abe-Ouchi, A., Ohgaito, R., Brady, E. C., and Hope, P.: The Southern Westerlies during the last glacial maximum in PMIP2 simulations, Clim. Dynam., 32, 525-548, doi:10.1007/s00382008-0421-7, 2009.

Shulmeister, J., Goodwin, I., Renwick, J., Harle, K., Armand, L., McGlone, M. S., Cook, E., Dodson, J., Hesse, P. P., Mayewski, P., and Curran, M.: The Southern Hemisphere westerlies in the Australasian sector over the last glacial cycle: a synthesis, Quatern. Int., 118-119, 23-53, 2004.
Sijp, W. P. and England, M. H.: Southern Hemisphere Westerly Wind Control over the Ocean's Thermohaline Circulation, J. Climate, 22, 1277-1286, 2009.

Solanki, S. K., Usoskin, I. G., Kromer, B., Schüssler, M., and Beer, J.: Unusual activity of the Sun during recent decades compared to the previous 11,000 years, Nature, 431, 1084-1087, 2004.

Spangehl, T., Cubasch, U., Raible, C. C., Schimanke, S., Körper, J., and Hofer, D.: Transient climate simulations from the Maunder Minimum to present day: Role of the Stratosphere, J. Geophys. Res.-Atmos., 115, D00I10, doi:10.1029/2009JD012358, 2010.

Steinhilber, F., Beer, J., and Fröhlich, C.: Total solar irradiance during the Holocene, Geophys. Res. Lett., 36, L19704, doi:10.1029/2009GL040142, 2009.

Thresher, R. E.: Solar correlates of Southern Hemisphere midlatitude climate variability, Int. J. Climatol., 22, 901-915, 2002.

Toggweiler, J. R. and Samuels, B.: Effect of Drake Passage on the global thermohaline circulation, Deep-Sea Res. Pt. 1, 42, 477500, 1995.

Toggweiler, J. R., Russel, J. L., and Carson, S. R.: Midlatitude westerlies, atmospheric $\mathrm{CO}_{2}$ and climate change during the ice ages, Paleoceanography, 21, PA2005, doi:10.1029/2005PA001154, 2006.

Tschumi, T., Joos, F., and Parekh, P.: How important are Southern Hemisphere wind changes for low glacial carbon dioxide? A model study, Paleoceanography, 23, PA4208, doi:10.1029/2008PA001592, 2008.

van Geel, B., Heusser, C. J., Renssen, H., and Schuurmans, J. E.: Climatic change in Chile at around $2700 \mathrm{BP}$ and global evidence for solar forcing: a hypothesis, Holocene, 10, 659-664, 2000.

Versteegh, G. J. M.: Solar forcing of climate, 2: Evidence from the Past, Space Sci. Rev., 120, 243-286, 2005.

Vonmoos, M., Beer, J., and Muscheler, R.: Large variations in Holocene solar activity: Constraints from ${ }^{10} \mathrm{Be}$ in the Greenland Ice Core Project ice core, J. Geophys. Res.-Space, 111, A10105, doi:10.1029/2005JA011500, 2006.

Yeager, S. G., Shields, C. A., Larger, W. G., and Hack, J. J.: The low-resolution CCSM3, J. Climate, 19, 2545-2566, 2006. 